\title{
OUR DEBT TO A VETERAN COLLECTOR.
}

Among the first and steadfast friends of the Historical Department has been the veteran collector of Keokuk, Dr. J. M. Shaffer. From time to time in years past we have received from him shipments of sundry sorts and-descriptions, consisting not only of documentary and literary materials of history, but of eurios and specimens. of industrial, military and natural history. Among these valuable contributions to our collections, Dr. Shaffer has given us old almanaes, army accoutrements, army regulations, old business forms, city directories and city ordinances, college catalogues, letters, maps, files of scientific and technical magazines, newspapers, scientific publications relating to astronomy, geology, mathematics, meteorology, and ornithology, old photographs of men and places, programs of conferences, entertainments, and all kinds of gatherings and meetings in the early and later history of the State. Among his gifts are to be mentioned a considerable body of material relating to the Iowa Life Insurance Company, of Keokuk, of which Dr. Shaffer was for many years president, consisting of correspondence, forms of application and policy, and methods of procedure. He has also presented not a little data in the way of accounts and reports of the Mississippi River Improvement schemes, the history of the Des Moines River Valley Railíoad, and papers and correspondence relative to the Centennial Exposition. Much, if not most, of the materials contributed by Dr. Shaffer is of a character but little appreciated by the average person, but which, when brought together in such collections as are now. forming in the Historical Department, catalogued and classified and made available, becomes of the highest order of importance to historical students.

Note. The insertion of the small map of Iowa prepared for the recent State census in our January number, showing early accessions of territory from the Indians, brought some criticisms of the map from early settlers in the State and others. An examination of the earlier surveys, and also of early maps of Wisconsin and Iowa Territories prepared by 
Deputy United States Surveyors from 1836 to 1845 , shows that some errors have crept into the recent map, and that some of the criticisms are justified. The map was drawn from blue prints furnished from the office of the Commissioner of Indian Affairs. In a later number we hope to give the exact or proximate boundaries of the various cessions of territory within the State, for the purpose of opening them to settlement, based on the field notes of the original surveys made under instructions from the Commissioner of Indian Affairs.

\section{NEW PUBLICATIONS.}

Early Settlement and Growth of Western Iowa, or Reminiscences, by Rev. John Todd of Tabor, Iowa. Des Moines, The Historical Department of Iowa, 1906, pp. 203.

The author of this interesting and valuable contribution to Iowa history was of Scotch-Irish stock, and brought into his life-work the sturdy elements which equally with the principles of the Puritans, of the $\mathrm{Hu}$ guenots, and the Quakers, have made America the homeland of Liberty and of an advancing civilization. He landed upon the rich lands of the Missouri Bottom at Civil Bend, in October, 1848, moved to the high lands near Tabor in April, 1852, and for forty-five years was a leader in transforming what had recently been an Indian wilderness into the cultivated fields and comfortable homes and pleasant cities and villages of American people. He threw his whole ardent nature and all the vigor of his quick and enlightened mind into the advancement of morality and religion, of industry and enterprise, with an unbounded zeal for temperance and human freedom, and for the establishment of schools and churches and Tabor College. Educated at Oberlin, Ohio, and thoroughly imbued with its spirit of saerifice and self-denial, he was always looking forward and moving onward for the improvement of human life both in the individual man and in the social order of the world. In missionary work an independent, making the essentials of religion his supreme concern, he affiliated with preachers of other denominations, and labored harmoniously with the Rev. William Simpson, the first Methodist, and the Rev. Launcelot. Graham Bell, the first Presbyterian minister, on the Missouri slope.

In 1854, the repeal of the compromise of 1820 , that admitted Missouri into the Union as a slave state and prohibited slavery west of it, proved a prelude to the civil war of 1861-'5. The repeal broke up the old Whig and Democratic parties, and led to the election of James W. Grimes as Governor of Iowa. He had canvassed the State in opposition to the repeal, and was elected on that issue. Upon learning that citizens of Iowa who had moved to Kansas were being spoiled and robbed by the minions of slavery, and that neither the authorities of the Territory nor of the Federal Government would give them the protection of law, Governor Grimes, August, 1856, wrote President Buchanan a letter of remonstrance, in which he stated that it would be the right and duty of the State of Iowa to protect her former citizens in Kansas, if the National Government failed to perform that duty. The Governor expressed 
Copyright of Annals of Iowa is the property of State of Iowa, by \& through the State Historical Society of Iowa and its content may not be copied or emailed to multiple sites or posted to a listserv without the copyright holder's express written permission. However, users may print, download, or email articles for individual use. 